\title{
TSH reference values for adult Brazilian population
}

\author{
Valores de referência do TSH para a população brasileira adulta
}

Pedro Weslley Rosario ${ }^{1,2}$, Arthur Cezar Malard Xavier1, Maria Regina Calsolari²

\begin{abstract}
Objective: To establish limits of normal serumTSH for the adult (18 to 60 years) Brazilian population according to recommendations of the National Academy of Clinical Biochemistry. Subjects and methods: Healthy volunteers were evaluated and those fulfilling the following clinical criteria were selected: absence of known thyroid disease; no use of any interfering medications; no history of head and neck external radiotherapy, type 1 diabetes or autoimmune disease; no family history of thyroid disease, and absence of goiter or palpable nodules. Subjects with anti-thyroperoxidase antibodies and/or altered free T4 were excluded. The sample consisted of 960 subjects (480 males and 480 females). Results: TSH values corresponding to the 2.5 th and 97.5 th percentiles of the sample were 0.43 and $3.24 \mathrm{mIU} / \mathrm{L}$, respectively. TSH values $>2.5 \mathrm{mIU} / \mathrm{L}$ were observed in $9.15 \%$ of the volunteers and levels $>3 \mathrm{mIU} / \mathrm{L}$ in $3.11 \%$. Conclusion: The present study suggests an upper limit of normalTSH of approximately $3.5 \mathrm{mIU} / \mathrm{L}$. Arq Bras Endocrinol Metab. 2010;54(7):603-6
\end{abstract}

\section{Keywords}

TSH; reference values; adult population

\section{RESUMO}

Objetivo: Estabelecer os limites de normalidade doTSH sérico em uma população adulta (18 a 60 anos) brasileira, conforme as recomendações da National Academy of Clinical Biochemistry. Sujeitos e métodos: Inicialmente foram avaliados voluntários saudáveis e selecionados aqueles sem doença tireoidiana conhecida, uso de medicamentos interferentes, passado de radioterapia externa de cabeça e pescoço, diabetes tipo 1 ou doença autoimune, história familiar de doença tireoidiana, bócio ou nódulos palpáveis. Indivíduos com anticorpos antitireoperoxidase (TPOAb) e/ou T4 livre alterado foram excluídos. A amostra foi composta de 960 participantes (480 de cada sexo). Resultad os: Os valores correspondentes aos percentis 2,5 e 97,5 da amostra foram 0,43 e 3,24 $\mathrm{mIU} / \mathrm{L}$, respectivamente. TSH > 2,5 mIU/L foi visto em 9,15\% dos indivíduos e $>3 \mathrm{mIU} / \mathrm{L}$ em $3,11 \%$. Conclusão: Nosso estudo sugere para a população adulta brasileira o limite superior normal doTSH de aproximadamente 3,5 mIU/L. Arq Bras Endocrinol Metab. 2010;54(7):603-6

\section{Descritores}

TSH; valores de referência; população adulta
Postgraduation Program, Santa Casa de Belo Horizonte, MG, Brazil ${ }^{2}$ Endocrinology Service, Santa Casa de Belo Horizonte, MG, Brazil

\section{INTRODUCTION}

$\mathrm{T}$ he current upper limit of normal serum TSH (approximately $4.5 \mathrm{mIU} / \mathrm{L}$ ) has been questioned over the past few years and its reduction to $2.5 \mathrm{mIU} / \mathrm{L}$ is being defended by many investigators $(1,2)$. Studies employing rigorous selection criteria, excluding subjects with thyroid disease not only based on clinical data but also on autoantibody measurement and ultrasonography (3), support this change. However, not all inves- tigators agree with this change $(4,5)$ and there are also careful studies reaffirming that the upper limit of normal TSH of about 3.5 to $4 \mathrm{mIU} / \mathrm{L}$ is adequate (6-12).

A reduction in the upper limit of normal for $\mathrm{TSH}$ has relevant consequences for the definition of subclinical hypothyroidism, with many patients currently classified as "euthyroid" being diagnosed with this condition, and for target TSH during levothyroxine (L-T4) replacement therapy, with many patients currently classified as "adequately treated" probably requiring treatment 
adjustment. Although TSH levels are not the only parameter evaluated for the initiation of L-T4 therapy or L-T4 dose adjustment, how much they differ from the upper normal limit will certainly influence the decision. On the basis of these implications, the adoption of lower TSH cut-off values requires discussion. On the other hand, in view of the possibility that many patients currently classified as "euthyroid" or "adequately treated" in fact are not, the subject cannot be minimized because of eventual economic consequences.

In view of this controversy, the objective of the present study was to establish reference limits of normal serum TSH for an adult (18 to 60 years) Brazilian population according to the recommendations of the $\mathrm{Na}$ tional Academy of Clinical Biochemistry (NACB) (1).

\section{SUBJECTS AND METHODS}

The population studied was from the metropolitan region of Belo Horizonte (Minas Gerais, Brazil). Apparently healthy volunteers of both genders were initially interviewed and examined, and those fulfilling the clinical criteria shown in table 1 were selected. Next, serum samples were obtained from the selected subjects in the morning (at about 8 a.m.) after an 8- to 10-h fast, and anti-thyroperoxidase antibodies (TPOAb), free T4 and TSH were measured. Subjects presenting positive TPOAb and/or altered free T4 were excluded. Ultrasonography (US) was not performed because of the following reasons: US is not required by the NACB (1); previous studies have shown no change in the reference limits of normal TSH when subjects with ultrasonographic anomalies were excluded from the initial sample $(3,7-9)$, a finding also demonstrated in a previous study from our group (13); and no consensus exists regarding the ultrasonographic findings $(3,6-9)$. A total of 1,802 volunteers were recruited; of these, $1,611(89.4 \%)$ agreed to be interviewed and examined and 641 were excluded because they did not fulfill the selection criteria. The sample was considered to be complete after the inclusion of 480 participants of each gender [pre-defined and larger than that required by the NACB (1)]. The age distribution of the samples was: 18 to 30 years $(n=220) ; 30$ to 45 years $(n=260)$ and 45 to 60 years $(n=480)$. The study was approved by the local Research Ethics Committee.

TSH was measured with a chemiluminescent assay (Immulite 2000, Diagnostic Products Corporation, Los Angeles, CA), with reference values of $0.4-4 \mathrm{mIU} / \mathrm{L}$,
Table 1. Inclusion criteria

\section{Clinical criteria}

Age 18 to 60 years

Not pregnant

Absence of thyroid disease, no current or previous treatment with antithyroid drugs or L-T4, no history of 1311 therapy or thyroidectomy

No use of potentially interfering medications such as dopaminergic agonists or antagonists, corticosteroids, estrogen, amiodarone, lithium, and anticonvulsants

No history of head and neck external radiotherapy

Absence of type 1 diabetes or other autoimmune diseases

No family history of thyroid disease

Absence of goiter or any palpable thyroid anomaly

Complementary criteria

Anti-TPOAb negative

Normal free T4

TPOAb: thyroperoxidase antibodies.

functional sensitivity of $0.02 \mathrm{mIU} / \mathrm{L}$, and intra- and interassay coefficients of variation $<7 \%$ for values ranging from 0.1 to $40 \mathrm{mIU} / \mathrm{L}$. TPOAb and free T4 were also measured by a chemiluminescent assay (Immulite 2000, Diagnostic Products Corporation, Los Angeles, $\mathrm{CA}$ ), with reference values up to $35 \mathrm{IU} / \mathrm{mL}$ and from 0.8 to $2.0 \mathrm{ng} / \mathrm{dL}$, respectively.

The reference limits of normal TSH were defined as follows: 1) 2.5th and 97.5th percentiles of the values obtained for the sample; 2) logarithmic transformation of the values obtained, calculation of the mean \pm 1.96 SD of these values, and exponentiation to obtain the limits corresponding to the original scale (1).

\section{RESULTS}

The distribution of TSH values in the sample is shown in figure 1 . The mean, median, minimum, maximum, and 2.5th and 97.5th percentiles of the values obtained were $1.52,1.4,0.35,4.8,0.43$ and $3.24 \mathrm{mIU} / \mathrm{L}$, respectively. TSH $>2.5 \mathrm{mIU} / \mathrm{L}$ was observed in $9.15 \%$ of the subjects and $>3 \mathrm{mIU} / \mathrm{L}$ in $3.11 \%$.

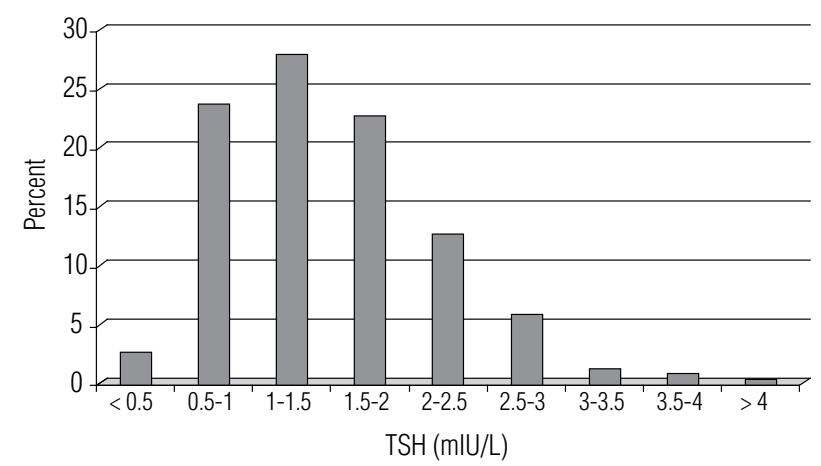

Figure 1. Distribution of TSH in the cohort $(n=960)$. 
The upper reference limit (mean + 1.96 SD) was estimated for the log-transformed data and then exponentiated back to the original scale. The resulting value (3.3 mIU/L) was very close to the 97.5 th percentile of TSH values $(3.24 \mathrm{mIU} / \mathrm{L})$.

\section{DISCUSSION}

We first would like to emphasize that the following discussion, as well as our results, cannot be extrapolated to children, women in the first trimester of gestation or subjects older than 70 years (11). Although the influence of other factors such as gender and race is possible, adjustment of TSH reference values for these factors is not recommended $(1,14)$.

In determining the TSH reference range, it has been customary to log-transform the data because of the skewed distribution (1). In fact, in the present study, TSH followed an approximate lognormal rather than Gaussian distribution. Nevertheless, the upper-reference limit based on "mean + 1.96 SD" of log-transformed TSH was very close to the 97.5 th percentile.

Since occult thyroid disease cannot be excluded based only on clinical evaluation and antibody measurement and since the inadvertent inclusion of these cases may overestimate the upper limit of TSH $(1,14)$, some studies have included ultrasonographic findings in the selection criteria of the population sample $(3,6-$ 10). Volzke and cols. (3), studying a previously iodine-deficient population, found an upper limit of TSH (97.5th percentile) of $2.12 \mathrm{mIU} / \mathrm{L}$. This result is in contrast to other studies that also excluded subjects with ultrasonographic anomalies and reported values of $3.6 \mathrm{mIU} / \mathrm{L}(5,6), 3.35 \mathrm{mIU} / \mathrm{L}(7), 3.77 \mathrm{mIU} / \mathrm{L}$ (8), $3.37 \mathrm{mIU} / \mathrm{L}(9)$, and $3.7 \mathrm{mIU} / \mathrm{L}$ (10). As can be seen, even in series including US, which is supposed to minimize the risk of overestimating TSH, the upper limit was approximately $3.5 \mathrm{mIU} / \mathrm{L}$, similar to the value found in the present study $(3.24 \mathrm{mIU} / \mathrm{L})$. Although the upper limits were similar, the comparison of the results of these different studies (5-10) is limited by population differences and the use of distinct TSH assays. Differences in the specificities of the anti-TSH monoclonal antibodies used and in how TSH glycofor$\mathrm{ms}$ are recognized by different immunoassays contribute to the need for assay-specific values (15). Furthermore, differences related to the distribution of these TSH isoforms and to iodine ingestion contribute to the need for population-specific TSH reference values.
Although patients without known or suspected thyroid disease and without antibodies may present ultrasonographic anomalies, the need of this method for sample selection to establish TSH reference values is questionable $(9,16)$. In the study of Kratsch and cols. (8), the upper limit of TSH changed from 3.63 to 3.77 $\mathrm{mIU} / \mathrm{L}$ when subjects with a family history of thyroid disease, antibodies or ultrasonographic anomalies were excluded from the initial sample. Hamilton and cols. (9) showed that the exclusion of subjects with altered US did not modify the value corresponding to the 97.5th percentile (3.37 mIU/L). Zöphel and cols. (7) reported that the initial sample and the reference sample (without antibodies and with normal US) yielded the same upper limit (97.5th percentile), 3.34 and 3.35 $\mathrm{mIU} / \mathrm{L}$, respectively. Even in the study of Volzke and cols. (3), no reduction in median TSH values (reported according to gender and age) was observed after the exclusion of subjects with TPOAb or ultrasonographic alterations. We also observed that the exclusion of 19 subjects presenting only an altered US from a sample of 169 patients without known or suspected thyroid disease, no family history and without TPOAb had no impact on the TSH upper limit (13). One current limitation of the use of US as a selection criterion is the discordance regarding the ultrasonographic findings. One study did not include glandular volume (9), another only considered nodules $>10 \mathrm{~mm} \mathrm{(3)}$, two did not consider alterations in echogenicity $(6,8)$, and one only included irregular hypoechogenicity (9). In addition, $641(39 \%)$ of the 1,611 subjects initially evaluated in this study were excluded, a fact demonstrating that the selection criteria adopted were highly restrictive.

In view of these doubts regarding the need of US for sample selection, studies that do not perform US cannot be neglected. In the NHANES III involving 13,344 subjects older than 12 years (excluding pregnant women) without known or laboratory evidence of thyroid disease $(\mathrm{TSH}<0.1 \mathrm{mIU} / \mathrm{L}$ or $>4.5 \mathrm{mIU} / \mathrm{L})$ and without antibodies (TPOAb or TgAb), the 97.5th percentile of TSH was $4.12 \mathrm{mIU} / \mathrm{L}$ (11). Jensen and cols. (12), studying 987 subjects aged 17 to 66 years (excluding pregnant women) without known thyroid disease or a family history and without antibodies, reported a value of $4.07 \mathrm{mIU} / \mathrm{L}$.

Consensus regarding the indication of treatment exists for subjects with persistent TSH $>10 \mathrm{mIU} / \mathrm{L}$, whereas treatment is not recommended for subjects with $\mathrm{TSH}<2.5 \mathrm{mIU} / \mathrm{L}(17)$. In cases presenting in- 
termediate values, TSH level is not the only parameter evaluated for the initiation of L-T4 therapy for subclinical hypothyroidism. It is essential that physicians consider various other patient-specific factors (17) before deciding whether thyroid hormone replacement therapy is indicated in an individual patient. If L-T4 replacement therapy is chosen, the upper limit of normal TSH should indeed be defined as the minimum value to indicate this therapy.

In a study also involving a Brazilian population (São Paulo), Duarte and cols. (10) evaluated 320 subjects aged 18 to 60 years (213 women) without known thyroid disease who were submitted to clinical examination and were TPOAb and US negative, and reported an upper limit of TSH of $3.7 \mathrm{mIU} / \mathrm{L}$. These findings and the results of the present study suggest that the upper limit of normal TSH for the adult Brazilian population would be approximately $3.5 \mathrm{mIU} / \mathrm{L}$, a limit lower than the traditional value of $4.5 \mathrm{mIU} / \mathrm{L}$ but not as low as the limit suggested by some investigators $(2.5 \mathrm{mIU} / \mathrm{L})(1,2)$.

Acknowledgments: This study was partly supported by SanofiAventis.

Disclosure: no potential conflict of interest relevant to this article was reported.

\section{REFERENCES}

1. Baloch Z, Carayon P, Conte-Devolx B, Demers LM, Feldt-Rasmussen $U$, Henry JF, et al. Laboratory support for the diagnosis and monitoring of thyroid disease. Thyroid. 2003;13:3-126.

2. Wartofsky L, Dickey RA. The evidence for a narrower thyrotropin reference range is compelling. $\mathrm{J}$ Clin Endocrinol Metab. 2005;90:5483-8.

3. Volzke H, Alte D, Kohlmann T, Ludemann J, Nauck M, John U, et al. Reference intervals of serum thyroid function tests in a previously iodine-deficient area. Thyroid. 2005;15:279-85.

4. Surks MI, Goswami G, Daniels GH. The thyrotropin reference range should remain unchanged. J Clin Endocrinol Metab. 2005;90:5489-96.
5. Brabant G, Beck-Peccoz P, Jarzab B, Laurberg P, Orgiazzi J, Szabolcs $I$, et al. Is there a need to redefine the upper normal limit of TSH? Eur J Endocrinol. 2006;154:633-7.

6. Knudsen N, Bulow I, Jorgensen T, Laurberg P, Ovesen L, Perrild H. Comparative study of thyroid function and types of thyroid dysfunction in two areas in Denmark with slightly different iodine status. Eur J Endocrinol. 2000;143:485-91.

7. Zöphel K, Wunderlich G, Grüning T, Koch R, Döge H, Kotzerke J. Where does subclinical hypothyroidism start? Implications for the definition of the upper reference limit for thyroid stimulating hormone (TSH). Nuklearmedizin. 2005;44:56-61.

8. Kratsch J, Fiedler GM, Leichtle A, Brugel M, Buchbinder S, Otto L, et al. New reference intervals for thyrotropin and thyroid hormones based on National Academy of Clinical Biochemistry criteria and regular ultrasonography of the thyroid. Clin Chem. 2005;51:1480-6.

9. Hamilton TE, Davis S, Onstad L, Kopecky KJ. Thyrotropin levels in a population with no clinical, autoantibody, or ultrasonographic evidence of thyroid disease: implications for the diagnosis of subclinical hypothyroidism. J Clin Endocrinol Metab. 2008;93:1224-30.

10. Duarte GC, Tomimori EK, Camargo RYA, Rubio IGS, Wajngarten M, Rodrigues AG, et al. The prevalence of thyroid dysfunction in elderly cardiology patients with mild excessive iodine intake in the urban area of São Paulo. Clinics. 2009;64:135-42.

11. Surks MI, Hollowell JG. Age-specific distribution of serum thyrotropin and antithyroid antibodies in the U.S. population: implications for the prevalence of subclinical hypothyroidism. J Clin Endocrinol Metab. 2007;92:4575-82.

12. Jensen E, Hyltoft Petersen P, Blaabjerg O, Hansen PS, Brix TH, Hegedüs $\mathrm{L}$. Establishment of a serum thyroid stimulating hormone (TSH) reference interval in healthy adults. The importance of environmental factors, including thyroid antibodies. Clin Chem Lab Med. 2004;42:824-32.

13. Borges MAR, Rosario PW, Purisch S. Normal serum TSH for our adult population. Congresso Mineiro de Endocrinologia 2007 (Abstract).

14. Spencer CA, Hollowell JG, Kazarosyan M, Braverman LE. National Health and Nutrition Examination Survey III thyroid-stimulating hormone (TSH)-thyroperoxidase antibody relationships demonstrate that TSH upper reference limits may be skewed by occult thyroid dysfunction. J Clin Endocrinol Metab. 2007;92:4236-40.

15. Rawlins ML, Roberts WL. Performance characteristics of six thirdgeneration assays for thyroid-stimulating hormone. Clin Chem. 2004;50:2338-44.

16. Zöphel K, Wunderlich G, Kotzerke J. Should we really determine a reference population for the definition of thyroid-stimulating hormone reference interval? Clin Chem. 2006;52:329-30.

17. Biondi B, Cooper DS. The clinical significance of subclinical thyroid dysfunction. Endocr Rev. 2008;29:76-131. 